\title{
Identification of a unique set of genes altered during cell-cell contact in an in vitro model of prostate cancer bone metastasis
}

\author{
JUN WANG, ANAIT S. LEVENSON and ROBERT L. SATCHER Jr
}

\author{
Department of Orthopaedic Surgery, and Robert H. Lurie Comprehensive Cancer Center, \\ The Feinberg School of Medicine, Northwestern University, Chicago, IL, USA
}

Received December 1, 2005; Accepted January 25, 2006

\begin{abstract}
The interaction between prostate cancer cells and bone marrow stromal cells (BMSC) is critical for survival and proliferation of metastatic cancer cells in the bone microenvironment. In order to study molecular mechanisms of prostate cancer bone metastasis, we established a novel heterotypic co-culture system, in which the role of direct cell-cell contact between prostate cancer cells and BMSC in addition to soluble factors can be analyzed. Using both bi-compartmental (insert) system and heterotypic (contact) system, we identified gene expression profiles of interaction between prostate cancer and bone cells. Analysis of differential gene expressions in these two co-culture systems revealed three distinctive sets of genes: 1) genes that were modified only by soluble factors; 2) genes that were regulated by both soluble factors and physical contact; and 3) genes that were altered only by physical contact. The last group consisted of specific set of genes including collagen III, IV, X, XII, integrin $\alpha 1, \alpha 2$, MMP-2, MMP-9, uPA, biglycan, osteopontin and raf-1 in PC3, and collagen VIII, IX, BMP6, TGFß1, Smad6 and Twist in BMSC. Among genes that were modified by both soluble factors and physical contact, the gene expression was affected in the same direction (such as MKK4) or in the opposite
\end{abstract}

Correspondence to: Dr Anait S. Levenson or Dr R.L. Satcher Jr, Department of Orthopaedic Surgery, The Feinberg School of Medicine, Northwestern University, 645 N. Michigan Avenue, Suite 910, Chicago, IL 60611, USA

E-mail: a-levenson@northwestern.edu r-satcher@northwestern.edu

Abbreviations: $\alpha \mathrm{MEM}, \alpha$-Eagle's minimum essential medium; BMP, bone morphogenetic protein; BMSC, bone marrow stromal cells; CFSE, Vybrant CFDA SE reagent; CSF, colony-stimulating factor; ECM, extracellular matrix; EGF, epidermal growth factor; GAPDH, glyceraldehydes-3-phosphate dehydrogenase; IGF, insulin-like growth factor; IGF-BP, insulin-like growth factorbinding protein; MAPK, mitogen-activated protein kinase; MKK4, mitogen-activated protein kinase kinase 4; MMP, matrix metalloproteinase; TGF, transforming growth factor; uPA, urokinase-type plasminogen activator; VCAM, vascular cell adhesion molecule

Key words: bone marrow stromal cells, bone metastasis, cell-cell contact, gene expression profile, prostate cancer direction (such as TGFß receptor 3). Overall, this suggests that heterotypic cell-cell contact may act as an independent factor affecting the progression of bone metastasis.

\section{Introduction}

Prostate cancer is the most common malignancy that occurs in adult males in the US. It is also the second leading cause of death from cancer in males (1). Skeletal metastases occur in as many as $70-80 \%$ of patients with advanced prostate cancer (2). Despite increasing research efforts, the molecular mechanisms responsible for the formation of bone metastases remain poorly understood. The process is complex and involves bi-directional interactions between tumor cells and bone $(3,4)$. Separating the effects of physical contact from those attributable to soluble factors has proven difficult. There are no universally accepted co-culture models that mimic physical contact in vitro. Also, it is difficult to study cell-cell interactions using complex in vivo models.

In vitro co-culture models have been used to study the soluble interactions between cancer cells and osteoblasts. For conditioned medium co-cultures, the supernatant from prostate cancer cells is used to treat osteoblasts, or vice versa. The interaction produced is uni-directional and only detects effects from soluble factors (5-10). Membrane insert systems add an additional level of complexity, modeling bi-directional interaction (11-13). An insert membrane contains 0.4-1.0 $\mu$ pores, and physically separates the two cell populations, so that only soluble factors are exchanged. Physical contact between unlike cells is not possible.

Physical contact between cancer and stromal cells is suspected to play an important role in metastasis formation and progression. The co-culture of intact mouse calvaria with prostate cancer cells stimulated bone mitogenesis that was greater than the response caused by conditioned medium (14). Barille et al (15) found that the physical contact between myeloma and osteoblastic cells up-regulated the secretion of interleukin-6 from osteoblasts. Direct cell-cell contact between laryngeal cancer cells and fibroblasts enhanced the production of pro-MMP-2 from cancer cells, which in turn increased the invasiveness of cancer cells (16). In their systems, cancer and stromal cells were co-cultured without any barriers. The mixed cells were not re-separated after the co-culture, and analysis consisted of detecting secreted factors (interleukin-6, MMP-2) in the supernatants of coculture medium. The characterization of each cell population 
in the co-culture was not pursued because of the technical difficulty in separating the mixed cells.

The present study describes a novel 'contact' in vitro system in which heterotypic physical contact between prostate cancer cells and BMSC was studied. After mixing and coculturing, the two cell populations were re-separated using fluorescence-activated cell sorting and quantified using flow cytometric analysis. Total RNA was isolated from the sorted cells. Gene expression profiles were then analyzed on gene arrays focused on tumor metastasis and osteogenesis. Genes and their related pathways that responded to physical contact alone were identified. They differed from genes regulated by soluble factors, implying that a separate mechanism is activated by physical contact. This 'contact' co-culture system can be potentially used to assess if contact regulated genes enhance the ability of metastasizing cells to survive and proliferate in the bone microenvironment.

\section{Materials and methods}

\section{Cell culture}

Bone marrow stromal cells. Monolayers of bone marrow stromal cells were harvested from 6-week-old Sprague-Dawley rats as described previously (17). After removal of the soft tissue, tibiae and femora of the rat were rinsed 3 times with sterile $100 \%$ ethanol. The epiphyses were removed, and the diaphysis was bisected longitudinally. The marrow was removed by repeatedly flushing with $10 \mathrm{ml}$ of $\alpha \mathrm{MEM}$ (Gibco, Gaithersburg, MD) supplemented with $10 \%$ fetal bovine serum (FBS), $100 \mathrm{U} / \mathrm{ml}$ penicillin-streptomycin and $2.5 \mathrm{mg} / \mathrm{ml}$ fungizone. The cells were passed through an 18-gauge needle to obtain a suspension of single cells, and then plated at 400,000 cells $/ \mathrm{cm}^{2}$. After $24 \mathrm{~h}$, the culture media was changed every other day to remove most non-adherent hematopoietic cells. On day 5 , the secondary medium ( $\alpha$ MEM supplemented with $10 \% \mathrm{FBS}, 100 \mathrm{U} / \mathrm{ml}$ penicillin-streptomycin, $2.5 \mathrm{mg} / \mathrm{ml}$ fungizone, and $50 \mu \mathrm{g} / \mathrm{ml} \mathrm{L-ascorbic} \mathrm{acid)} \mathrm{was} \mathrm{used} \mathrm{to} \mathrm{culture}$ the cells to reach confluence.

Prostate cancer cell line PC3. PC3 cell line, obtained from American Type Culture Collection (Rockville, MD), is androgen unresponsive and derived from metastasis to bone marrow. The cells were maintained in RPMI-1640 culture medium (Gibco) supplemented with $10 \%$ FBS and $100 \mathrm{U} / \mathrm{ml}$ penicillin-streptomycin and $2.5 \mathrm{mg} / \mathrm{ml}$ fungizone at $37^{\circ} \mathrm{C}$ with $5 \% \mathrm{CO}_{2}$.

Cell labeling. PC3 cells were labeled with Vybrant ${ }^{\mathrm{TM}}$ CFDA SE reagent (CFSE) purchased from Molecular Probes (Eugene, $\mathrm{OR}$ ). The cells were incubated with phosphate-buffered saline containing $15 \mu \mathrm{M}$ CFSE for $15 \mathrm{~min}$. CFSE passively diffuses into PC3 cells and forms highly fluorescent dye-protein adducts, which were retained by the cells for up to eight days. The CFSE solution was replaced with supplemented aMEM containing $10 \%$ FBS. The cells were incubated for an additional $30 \mathrm{~min}$ to $1 \mathrm{~h}$ for further analysis.

Physical contact co-culture system and insert co-culture system. The CFSE-labeled PC3 cells were mixed and cocultured with BMSC in supplemented aMEM containing $10 \%$ FBS. The initial seeding density was determined by the

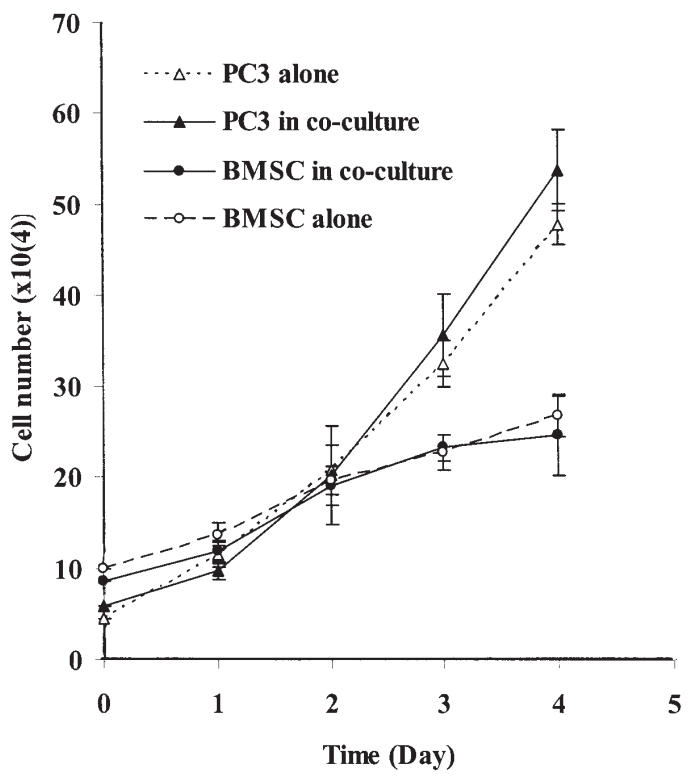

Figure 1. Proliferation curves of PC3 and BMSC in the physical contact coculture system. The proliferation rates were not changed compared with culture alone. The ratio between two types of cells on day 2 was approximately $1: 1$. The data show mean and standard deviation of three independent experiments.

growth rates (doubling time) of PC3 and BMSC when they were cultured separately. Since there is no barrier between the two populations, effects are produced from both the exchange of soluble factors and from physical contact when unlike cells touch. As a comparison to the physical contact co-culture system, PC3 cells and BMSC were also co-cultured in a bicompartmental system by using Falcon ${ }^{\mathrm{TM}}$ cell culture inserts ( $1 \mu$ pore on polyethylene terephthalate membrane), which were purchased from Becton Dickson Labware (Franklin Lakes, NJ). In this case, two types of cells shared the culture medium but were not in physical contact.

Flow cytometry analysis and fluorescence-activated cell sorting. Flow cytometric analysis of co-cultured cells was performed on an Epics XL-MCL cytometer (Beckman Coulter, Fullerton, CA). The fluorescence was detected by using excitation at $488 \mathrm{~nm}$ and diachronic/band long pass filters. The results were analyzed with instrument software System II 3.0. Fluorescence-activated cell sorting was performed by using an Elite ESP cell sorter (Beckman Coulter), which is fitted with four lasers and provides emission wavelengths ranging from 350 to $647 \mathrm{~nm}$. The droplet cell-sorting function was used to separate fluorescencepositive cells from fluorescence-negative cells.

Northern blot analysis. Total RNA was extracted from the cells using Trizol reagent (Gibco). Northern blot analysis was performed as described previously (18). Briefly, RNA samples $(15-20 \mu \mathrm{g})$ were fractionated in a $1.2 \%$ formaldehyde-agarose gel and transferred to a nylon membrane (Hybond- $\mathrm{N}^{+}$, from Amersham, Piscataway, NJ). Human or rat cDNA probes for the appropriate gene were labeled with ${ }^{32} \mathrm{P}$ and used for hybridization. Subsequently, the blots were stripped and hybridized with a probe for $\beta$-actin as a loading control. The 
A

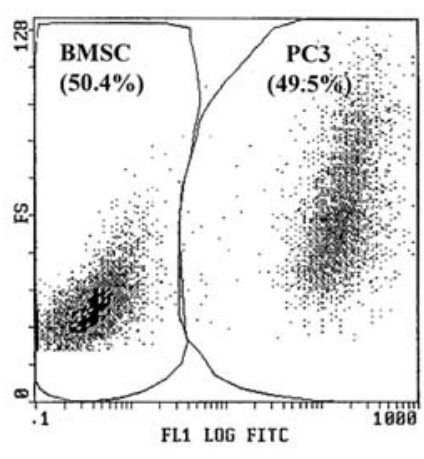

B
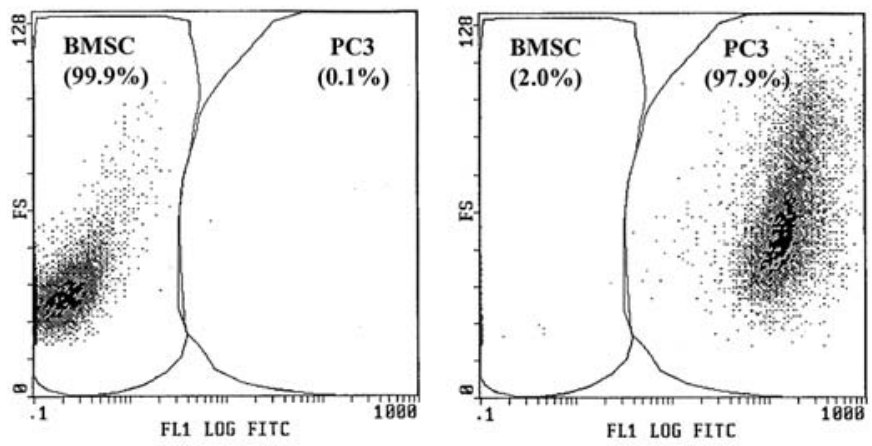

Figure 2. Flow cytometric analysis of contact co-culture prior to (A) and after cell sorting (B). PC3 cells were mixed and co-cultured with BMSC for $48 \mathrm{~h}$. The two cell populations had approximately equal numbers $(50.4 \%$ BMSC vs. $49.5 \%$ PC3). PC3 cells (CSFE+) and BMSC (CFSE-) were then re-separated through fluorescence-activated cell sorting. The purity of BMSC and PC3 cells was 99.9 and $97.9 \%$, respectively. The data represent at least three independent experiments.

signals were scanned and quantified with Scion image software (Scion, Frederick, MD).

cDNA gene array and data analysis. The GEArray Q series human tumor metastasis gene array, human osteogenesis gene array, and mouse osteogenesis gene array, were purchased from SuperArray Inc. (Frederick, MD). The gene tables are available at www.superarray.com. The labeling and hybridization procedures were conducted as specified by the manufacturer. Both human tumor metastasis gene array and human osteogenesis gene array, each containing 96 genes, were used to study the gene expression profiles of PC3 cells. Sixteen genes appear on both types of arrays, including FGF1, FGF2, IGF-II, integrin $\alpha 2, \alpha 3, \beta 1$, MMP $2,8,9,10,13, \operatorname{PDGF} \alpha$, osteopontin, TGFß1, VEGF and VEGF-C. These genes are known to be involved in both tumor metastasis and bone formation process. Since a rat osteogenesis array was not available, a mouse osteogenesis array was used to investigate the gene expression profile of BMSC. The cDNA probe was amplified and labeled according to the protocol for the AmpoLabeling-LPR kit (SuperArray, Inc.). Briefly, total RNA $(2 \mu \mathrm{g})$ extracted from the cells was first annealed with a random primer at $70^{\circ} \mathrm{C}$ for $3 \mathrm{~min}$, then reverse transcribed to cDNA at $37^{\circ} \mathrm{C}$ for $25 \mathrm{~min}$. These cDNAs were amplified by PCR with gene-specific primers and presence of biotin-16-
dUTP (Roche Diagnostics, Indianapolis, IN). The PCR cycle was $85^{\circ} \mathrm{C}$ for $5 \mathrm{~min} ; 30$ cycles of: $85^{\circ} \mathrm{C}$ for $1 \mathrm{~min}, 50^{\circ} \mathrm{C}$ for $1 \mathrm{~min}$, and $72^{\circ} \mathrm{C}, 1 \mathrm{~min}$; and $72^{\circ} \mathrm{C}$ for $5 \mathrm{~min}$. The probes were then hybridized with tumor metastasis gene array or osteogenesis gene array at $60^{\circ} \mathrm{C}$ for $17 \mathrm{~h}$. Next, the array filters were washed twice with $2 \mathrm{X}$ standard saline citrate (SSC)/1\% SDS and then twice with $0.1 \mathrm{X} \mathrm{SSC} / 1 \% \mathrm{SDS}$ at $60^{\circ} \mathrm{C}$ for $15 \mathrm{~min}$ each. Chemiluminescent detection steps were performed by subsequent incubation of the filters with alkaline phosphataseconjugated streptavidin and CDP-Star substrate and exposure to electrochemiluminescence film. After scanning the film, the intensity of spots was first measured by ScanAlyze software. The expression data were then analyzed using a GEArray analyzer. After background subtraction, normalization was performed for each gene against the housekeeping gene GAPDH. Based on the average of three independent experiments, comparisons were performed between arrays for co-cultured cells versus arrays for solely cultured cells by using Student's t-test analysis. The ratio $>2$ (for up-regulated genes) or $<0.5$ (for down-regulated genes) and with P-value $<0.05$ was considered significant.

$R T-P C R$. Human or rat primers for RT-PCR were purchased from SuperArray Inc. cDNA was synthesized using $1 \mu \mathrm{g}$ total RNA in the presence of SuperScript III and oligo(dT)20 (both from Invitrogen, Carlsbad, CA). The PCR was performed in a $25-\mu 1$ reaction solution containing $12.5 \mu 1$ of AccuPrime Super-Mix I, $0.4 \mu \mathrm{M}$ of specific gene primers, $0.2 \mu \mathrm{M}$ of GAPDH internal normalizer primers and $1 \mu \mathrm{l}$ of $10 \mathrm{X}$ diluted template cDNA. After denaturing the template and activating the polymerase at $94^{\circ} \mathrm{C}$ for $2 \mathrm{~min}$, the PCR reaction was run for $30-40$ cycles at: $94^{\circ} \mathrm{C}$ for $15 \mathrm{sec}, 55^{\circ} \mathrm{C}$ for $30 \mathrm{sec}$, and $68^{\circ} \mathrm{C}$ for $60 \mathrm{sec}$. The results were normalized by internal loading control of the human GAPDH gene (226 bp) or rat GAPDH gene (217 bp).

\section{Results}

Establishment and characterization of physical contact coculture system. When CFSE-labeled PC3 cells and BMSC were co-cultured with direct cell-cell contact, the fluorescence label in PC3 cells was inherited by daughter cells after cell division, but was not transferred to adjacent BMSC in the co-culture population. The proportion of the cell population was measured using flow cytometry up to four days. It showed that the proliferation of two types of cells was not significantly changed during the co-culture (Fig. 1). After co-culturing for $48 \mathrm{~h}$, the ratio between PC3 cells and BMSC was approximately 1:1 (Fig. 2A). It was demonstrated previously that heterotypic contact is maximized at 1:1 cell ratio (17). Fluorescence-activated cell sorting was then performed to separate fluorescence-positive cells (PC3) and fluorescencenegative cells (BMSC). Co-cultured cells $\left(3 \times 10^{6}\right)$ were sorted and $0.9-1.2 \times 10^{6}$ of each type was obtained after cell sorting. The recovery rate was between 60 and $80 \%$. The purity was 96-98\% for PC3 cells and 99-100\% for BMSC (Fig. 2B).

Northern blot analysis of metastasis- and osteogenesisrelated genes was used to validate the contact co-culture system (Fig. 3). Physical contact produced specific effects on some genes in addition to the effects of soluble factors. In 
A

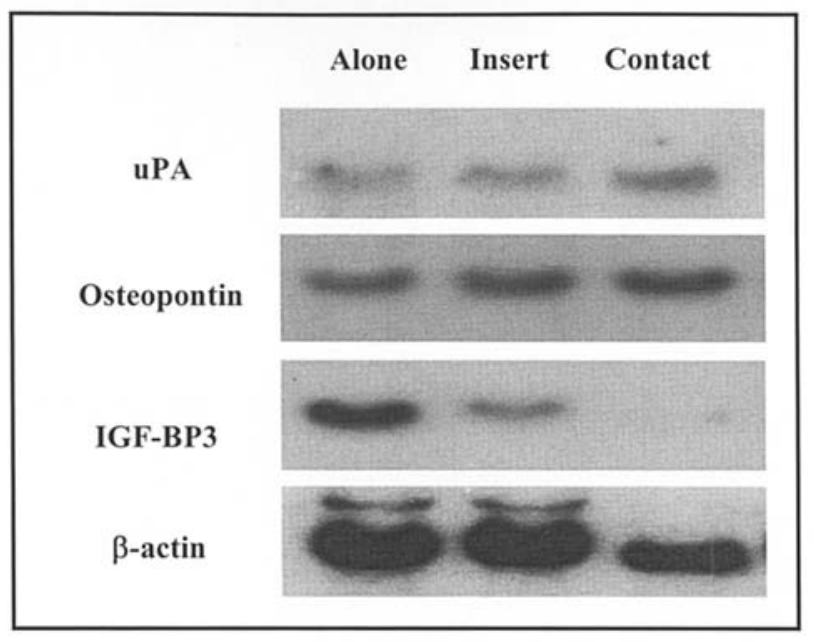

B

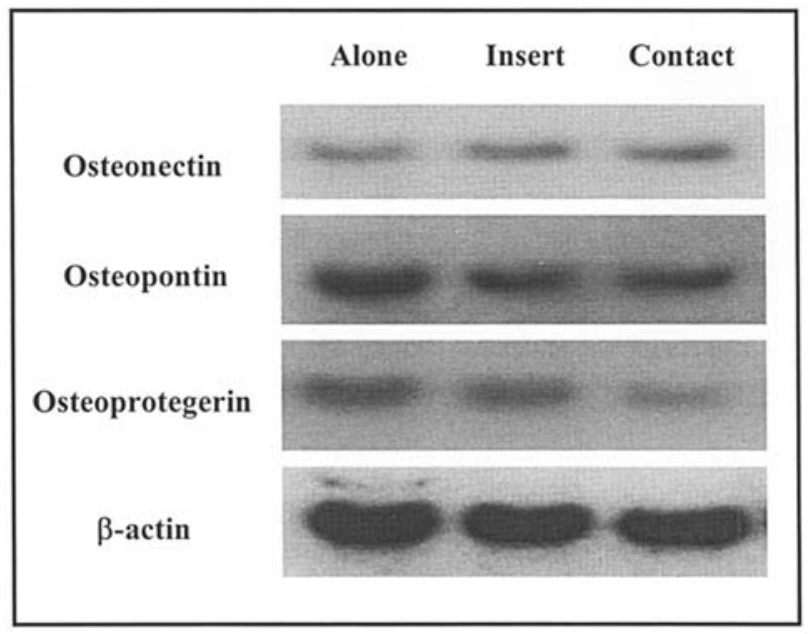

Figure 3. The effects of soluble factors and physical contact on selected genes in PC3 (A) and BMSC (B) analyzed by Northern blotting. Total RNA was extracted from solely cultured cells (Alone), cells co-cultured in the insert system (Insert) and cells co-cultured in the contact system (Contact) as described in Materials and methods. The expression of uPA, osteopontin and IGF-BP3 were detected in PC3 cells. The expression of osteonectin, osteopontin and osteoprotegerin were detected in BMSC. B-actin was used as a loading and normalization control.

PC3 cells, the expression of uPA and osteopontin was slightly increased in the contact system compared to the insert system. In contrast, the expression of IGF-BP3 was decreased in the insert system, and was further reduced in the contact system. In BMSC, there was no change in the expression of osteonectin and osteopontin, but osteoprotegerin was down-regulated, particularly in the contact system.

Gene expression profiles of PC3 cells and BMSC during physical contact. Using total RNA from PC3 cells, 75 genes were detected on the human tumor metastasis array and 63 genes were detected on the human osteogenesis array. They include genes that function as growth factors, growth factor receptors, ECM proteins, cell adhesion molecules, proteases and their inhibitors, signal transduction molecules and transcription factors, oncogenes and metastasis suppressors. Using total RNA from BMSC, 49 genes were detected on the osteogenesis array that included growth factors and

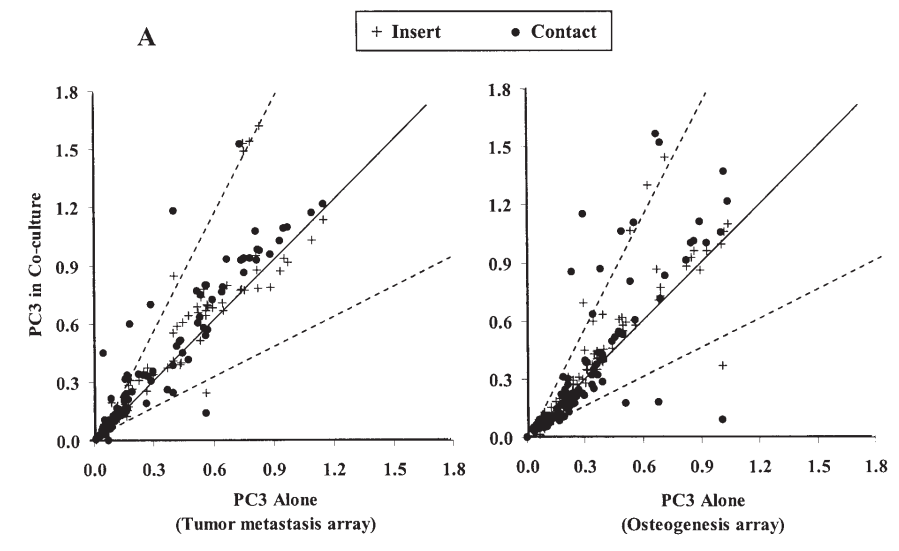

B

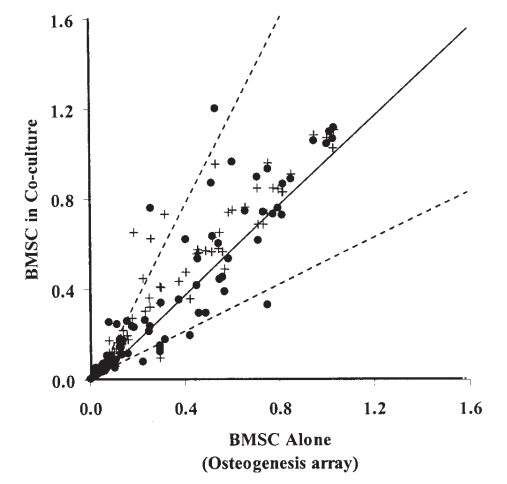

Figure 4. Gene expression profiles of PC3 cells on human tumor metastasis gene array and human osteogenesis gene array (A), and of BMSC on mouse osteogenesis gene array (B). The relative gene expression values (y-axis) in co-cultured cells from insert system (Insert) or from contact system (Contact) were plotted against those of solely cultured cells (Alone, X-axis). Genes lined up on the diagonal line $(\mathrm{y}=\mathrm{x}$, solid line) were not up- or downregulated during the co-culture. Genes outlined above the line $y=2 x$ (upper dashed line) were up-regulated at least two-fold, whereas genes outlined beneath the line $y=x / 2$ (lower dashed line) were down-regulated at least one half. The data represent the average of three independent experiments.

receptors, ECM protein, cell adhesion molecules, protease and transcription factors.

The relative expression levels in co-culture with physical contact, and in the insert co-culture system (no physical contact) versus PC3 alone are plotted for the human tumor metastasis array and the human osteogenesis array (Fig. 4A). The results for BMSC using the mouse osteogenesis array are also shown (Fig. 4B). The genes for which expression was not affected by co-culture occur along the diagonal line $(y=x)$. Genes that were up-regulated at least two-fold $(\mathrm{y}=2 \mathrm{x})$ or downregulated at least one half $(\mathrm{y}=\mathrm{x} / 2)$ are identified lying outside the dashed lines on Fig. 4. The patterns of gene expression for cells exposed to contact co-culture are different from co-culture that permitted soluble interactions only (i.e. the insert co-culture system).

Different sets of genes regulated by physical contact and soluble factors. Three sets of genes were identified and classified according to the mode of regulation (i.e. in physical contact system, in insert system, or in both) so that the different effects of physical contact and soluble factors were distinguished. 
Table I. Genes regulated only in the physical contact system during the co-culture of PC3 and BMSC.

\begin{tabular}{|c|c|c|c|}
\hline $\begin{array}{l}\text { GeneBank } \\
\text { accession no. }\end{array}$ & Gene name & $\begin{array}{l}\text { Fold change in } \\
\text { contact system }\end{array}$ & P-value \\
\hline \multicolumn{4}{|l|}{ PC3 } \\
\hline J04599 & Biglycan & 2.3 & 0.035 \\
\hline NM_000090 & Collagen III $\alpha 1$ & 3.7 & 0.016 \\
\hline X05610 & Collagen IV $\alpha 2$ & 2.4 & 0.044 \\
\hline NM_000493 & Collagen X $\alpha 1$ & 0.3 & 0.040 \\
\hline NM_004370 & Collagen XII $\alpha 1$ & 0.3 & 0.014 \\
\hline X68742 & Integrin a1 & 2.2 & 0.037 \\
\hline X17033 & Integrin $\alpha 2$ & 2.2 & 0.032 \\
\hline J03210 & MMP-2 & 8.9 & 0.0002 \\
\hline $\mathrm{J} 05070$ & MMP-9 & 3.2 & 0.003 \\
\hline M83248 & Osteopontin & 2.1 & 0.050 \\
\hline X03484 & Raf-1 & 1.9 & 0.047 \\
\hline D00244 & uPA & 1.9 & 0.045 \\
\hline \multicolumn{4}{|l|}{ BMSC } \\
\hline NM_007556 & BMP6 & 0.5 & 0.033 \\
\hline NM_007739 & Collagen VIII $\alpha 1$ & 0.4 & 0.020 \\
\hline NM_007740 & Collagen IX $\alpha 1$ & 0.5 & 0.041 \\
\hline NM_008542 & Smad6 & 0.4 & 0.020 \\
\hline M13177 & TGFß1 & 2.3 & 0.049 \\
\hline NM_011658 & Twist & 2.2 & 0.035 \\
\hline
\end{tabular}

${ }^{a}$ The fold change in the contact system showed the mean of the ratio between contact co-culture and culture alone in three independent experiments. ${ }^{\text {bP-value }}(<0.05)$ showed significant difference between contact co-culture and culture alone.

1) Genes that were up/down-regulated only in the physical contact system, included biglycan, collagen III, collagen IV, collagen X, collagen XII, integrin $\alpha 1$, integrin $\alpha 2$, MMP-2, MMP-9, osteopontin, raf-1, uPA in PC3, and BMP6, collagen VIII, collagen IX, Smad6, TGFß1, Twist in BMSC (Table I). The regulation of these genes requires physical contact. Exposure to soluble factors alone did not regulate expression.

2) Genes that were modified only in the insert system included CSF-1, cystatin C, fibronectin-1, H-ras, laminin B2, TGFß receptor 1 in PC3, and CSF-2, VCAM-1 in BMSC (Table II). These genes were regulated by soluble factors alone, but were not modified by the combination of soluble factors and physical contact. It suggested that physical contact might eliminate the effects of soluble factors on these genes.

3) Genes that were regulated in both systems included cathepsin K, CSF-1 receptor, EGF receptor, MKK4, mta-1, Smad9 in PC3, and cathepsin K, decorin, TGFß receptor 1, TGF 3 receptor 3 in BMSC (Table III). For many of these genes, the magnitude of up/down-regulation was similar in both systems $(\mathrm{P}>0.05)$, which suggested that physical contact did not affect the gene regulation by soluble factors. However, the MKK4 and TGFß receptor 3 genes were significantly different in the two systems. The expression of MKK4 in PC3 cells was down-regulated more in the contact system
Table II. Genes regulated only in the insert system during the co-culture of PC3 and BMSC.

\begin{tabular}{llcc}
\hline $\begin{array}{l}\text { GeneBank } \\
\text { accession no. }\end{array}$ & Gene name & $\begin{array}{c}\text { Fold change in } \\
\text { insert system }\end{array}$ & P-value \\
\hline PC3 & & & \\
M37435 & CSF-1 & 2.0 & 0.042 \\
NM_000099 & Cystatin C & 2.0 & 0.050 \\
X02761 & Fibronectin-1 & 2.0 & 0.037 \\
NM_005343 & H-ras & 2.0 & 0.040 \\
J03202 & Laminin B2 & 1.9 & 0.050 \\
L11695 & TGFßR1 & 2.0 & 0.048 \\
BMSC & & & \\
X03020 & CSF-2 & 2.3 & 0.040 \\
M84487 & VCAM-1 & 3.5 & 0.011 \\
\hline
\end{tabular}

aThe fold change in the insert system showed the mean of the ratio between insert co-culture and culture alone in three independent experiments. ${ }^{\text {bP-value }}(<0.05)$ showed significant difference between insert co-culture and culture alone.

compared to the insert system $(\mathrm{P}<0.05)$. This implies that the effects of soluble factors on MKK4 were enhanced by physical contact. The expression of TGFß receptor 3 in BMSC was increased in the insert system, but decreased in the contact system $(\mathrm{P}<0.05)$, suggesting that TGFß receptor 3 was stimulated by soluble factors, but suppressed by physical contact. Physical contact showed opposing effects to soluble factors on the expression of TGFß receptor 3 .

Validation of array data by $R T-P C R$. To validate array results, the entire set of genes regulated in the physical contact system (Table I and III) was analyzed using semi-quantitative RTPCR for PC3 cells (Fig. 5) and BMSC (Fig. 6). The RT-PCR results were consistent with gene array data as to the up- or down-regulation of these genes. In most cases, the fold changes detected by RT-PCR were similar to those detected in gene array. For some genes, the changes were significantly different. For instance, the expression of biglycan in PC3 cells was increased 419.5 -fold in the contact system by RT-PCR. In contrast, it was up-regulated only 2.3-fold on gene array. On the other hand, Smad 6 in BMSC was suppressed 100-fold by RT-PCR, but only decreased about two-fold in gene array. The differences between RT-PCR and array results might be due to the different sensitivity on low signal intensity. Overall, the array results were confirmed by RT-PCR.

\section{Discussion}

A novel in vitro co-culture model was designed and tested that allows both soluble interaction and physical contact between constituent cells. Among the detected genes on arrays, 18 genes in PC3 and ten genes in BMSC (Table I and III) were found to be regulated in the contact co-culture system. An insert co-culture system was used for comparison, so that gene regulation resulting from soluble factors alone could be 
Table III. Genes regulated in the physical contact system and insert system during the co-culture of PC3 and BMSC.

\begin{tabular}{|c|c|c|c|c|}
\hline $\begin{array}{l}\text { GeneBank } \\
\text { accession no. }\end{array}$ & Gene name & $\begin{array}{l}\text { Fold change in } \\
\text { insert system } \\
(\mathrm{P} \text {-value })^{\mathrm{b}}\end{array}$ & $\begin{array}{c}\text { Fold change in } \\
\text { contact system }{ }^{\mathrm{a}} \\
\quad(\mathrm{P}-\mathrm{value})^{\mathrm{b}}\end{array}$ & $\begin{array}{c}\text { Insert vs. Contact } \\
\text { P-value }\end{array}$ \\
\hline \multicolumn{5}{|l|}{ PC3 } \\
\hline NM_000396 & Cathepsin K & $2.4(0.032)$ & $3.9(0.010)$ & $>0.05$ \\
\hline X03663 & CSF-1R & $2.1(0.041)$ & $2.9(0.039)$ & $>0.05$ \\
\hline X00588 & EGFR & $0.3(0.001)$ & $0.2(0.001)$ & $>0.05$ \\
\hline L36870 & MKK4 & $0.4(0.003)$ & $0.2(0.0009)$ & 0.019 \\
\hline U35113 & Mta-1 & $2.3(0.038)$ & $2.5(0.043)$ & $>0.05$ \\
\hline NM_005905 & Smad9 & $2.1(0.044)$ & $3.1(0.020)$ & $>0.05$ \\
\hline \multicolumn{5}{|l|}{ BMSC } \\
\hline NM_007802 & Cathepsin $\mathrm{K}$ & $2.2(0.040)$ & $3.1(0.031)$ & $>0.05$ \\
\hline NM_007833 & Decorin & $2.4(0.042)$ & $3.0(0.040)$ & $>0.05$ \\
\hline D28526 & TGFßR1 & $0.3(0.025)$ & $0.5(0.036)$ & $>0.05$ \\
\hline AF039601 & TGFßR3 & $2.0(0.050)$ & $0.4(0.002)$ & 0.001 \\
\hline
\end{tabular}

${ }^{a}$ The fold change in the insert system or in the contact system showed the mean of the ratio between insert co-culture or contact co-culture and culture alone in three independent experiments. ${ }^{b} \mathrm{P}$-value $(<0.05)$ showed significant difference between co-culture (insert system or contact system) and culture alone. ${ }^{\mathrm{c}} \mathrm{P}$-value of insert vs. contact showed the difference between insert co-culture and contact co-culture. $\mathrm{P}<0.05$ was considered statistically significant.

identified. Physical contact and soluble factors are separate processes in the mechanism for regulating gene expression during metastasis formation. This co-culture system may more closely mimic the real situation in vivo than previous in vitro models, and can be potentially used to seek new molecular targets for metastasis treatment that interfere with tumor and bone interaction.

The contact co-culture model is most relevant to early events in the mechanism of skeletal metastasis formation. When small numbers of tumor cells first metastasize to bone, most of the tumor cells come into direct contact with bone marrow stromal cells. Contact induced events and local soluble factors (such as growth factors) may play critical roles in regulating adhesion, invasion and proliferation of metastatic tumor cells.

Rat BMSC were initially chosen for testing the co-culture model system because large numbers of cells were required to benchmark the system. Primary BMSC from human and mouse will be subsequently tested. Rat gene arrays were not commercially available; therefore, mouse arrays were used to analyze rat RNA given the high degree of homology between genes from the two different species. The relative gene expression level was verified using two independent and species-specific methods (i.e. Northern blot and RT-PCR). The results using both detection methods were independently consistent for gene regulation.

Several gene families and signal transduction pathways were affected by the interaction between prostate cancer cells and BMSC and will be further discussed: a) TGFß superfamily genes, including BMPs, TGFß and TGFß receptor, and their downstream signal transduction molecules Smad; b) colony stimulating factors, such as CSF-1, CSF-2 and CSF-1 receptor; c) extracellular matrix protein and cell adhesion molecules, including various types of collagen family (type III, IV, VIII, IX, $\mathrm{X}$ and XII), other bone matrix proteins (fibronectin-1, laminin B2, biglycan, osteopontin and decorin), and related cell adhesion molecules (integrin $\alpha 1, \alpha 2$, VCAM-1); d) extracellular matrix protease and their inhibitors, such as cathepsin K, MMP-2, MMP-9, uPA and cystatin C; and e) MAPK signal transduction molecules, including MKK4, mta-1 and raf-1.

Extracellular matrix proteases may play a crucial role in facilitating metastatic cell survival in the bone microenvironment. The role of uPA in prostate cancer bone metastasis has been well investigated (19). uPA promotes tumor metastasis by degrading ECM and activating growth factors in bone matrix. uPA also acts as a mitogen inducing osteoblast proliferation. Inhibiting uPA expression in prostate cancer cells not only decreased tumor growth, but also reduced osteolysis in bone from metastases (20). The up-regulation of uPA in the current studies was detected by all three methods used (gene array, Northern blot and RT-PCR) as well as in our previous studies using a micro-patterned co-culture system (17).

Besides uPA, some other ECM proteases also appear to enhance metastasis formation by modifying the components of ECM, and in turn changing the properties of cell-cell adhesion through integrin molecules and cell-matrix adhesion through cell adhesion molecules (21). MMPs play a major role in proteolytic degradation of components of extracellular matrix (22). MMP-2 and MMP-9, in particular, have been found to be specifically associated with prostate cancer metastasis $(23,24)$. The highest fold increase for MMP-2 (8.9-fold) observed in PC3 cells occurred among genes regulated by physical contact only (Table I), suggesting its critical role for metastasis progression. Besides MMPs, cathepsin is another family of cysteine proteases that may degrade ECM components and 


\begin{tabular}{|c|c|c|c|c|c|}
\hline & A & I & C & $\begin{array}{l}\text { Ratio } \\
\text { (I/A) }\end{array}$ & $\begin{array}{l}\text { Ratio } \\
\text { (C/A) }\end{array}$ \\
\hline $\begin{array}{l}\text { Biglycan } \\
\text { (423bp) }\end{array}$ & $\rightarrow-$ & -1 & 24 & 1.0 & 419.5 \\
\hline $\begin{array}{l}\text { Collagen III } \alpha 1 \\
\quad(530 \mathrm{bp})\end{array}$ & & $\rightarrow$ & $=4$ & 0.9 & 11.8 \\
\hline $\begin{array}{l}\text { Collagen IV } \alpha 2 \\
\quad \text { (453bp) }\end{array}$ & $\rightarrow=$ & - & $\simeq 4$ & 0.8 & 1.9 \\
\hline $\begin{array}{c}\text { Collagen } X \propto 1 \\
\quad(524 b p)\end{array}$ & & 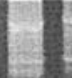 & 5 & 1.1 & 0.4 \\
\hline $\begin{array}{c}\text { Collagen XII } \alpha 1 \\
\quad(166 \mathrm{bp})\end{array}$ & $\rightarrow E$ & 존 & $=4$ & 1.1 & 0.3 \\
\hline $\begin{array}{l}\text { Integrin } \alpha 1 \\
(157 \mathrm{bp})\end{array}$ & 5 & $=:$ & $=4$ & 0.8 & 1.9 \\
\hline $\begin{array}{c}\text { Integrin } \alpha 2 \\
(155 \mathrm{bp})\end{array}$ & $\rightarrow=$ & $\Rightarrow$ & $n 4$ & 1.3 & 2.8 \\
\hline $\begin{array}{l}\text { MMP-2 } \\
\text { (157bp) }\end{array}$ & $=$ & 6 & $=4$ & 1.1 & 4.6 \\
\hline $\begin{array}{l}\text { MMP-9 } \\
\text { (604bp) }\end{array}$ & & \pm & 4 & 1.2 & 2.3 \\
\hline $\begin{array}{l}\text { Osteopontin } \\
\text { (152bp) }\end{array}$ & & (18) & $=4$ & 0.9 & 2.1 \\
\hline $\begin{array}{c}\text { Raf-1 } \\
\text { (667bp) }\end{array}$ & - & E! & 24 & 1.1 & 2.3 \\
\hline $\begin{array}{c}\text { uPA } \\
(155 \mathrm{bp})\end{array}$ & $=$ & $\equiv$ & $\approx 4$ & 0.9 & 2.4 \\
\hline $\begin{array}{c}\text { Cathepsin K } \\
\text { (583bp) }\end{array}$ & & 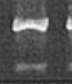 & 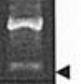 & 2.9 & 3.2 \\
\hline $\begin{array}{l}\text { CSF-1R } \\
\text { (480bp) }\end{array}$ & 4 & & & 2.3 & 2.8 \\
\hline $\begin{array}{c}\text { EGFR } \\
(655 b p)\end{array}$ & $\sim$ & - & - & 0.7 & 0.2 \\
\hline $\begin{array}{l}\text { MKK4 } \\
\text { (618bp) }\end{array}$ & $=$ & 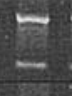 & -4 & 0.5 & 0.2 \\
\hline $\begin{array}{c}\text { Mta-1 } \\
\text { (442bp) }\end{array}$ & $\rightarrow-$ & -4 & $=4$ & 2.8 & 5.8 \\
\hline $\begin{array}{l}\text { SMAD9 } \\
\text { (537bp) }\end{array}$ & $\rightarrow+$ & 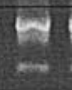 & 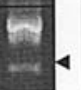 & 2.1 & 2.8 \\
\hline
\end{tabular}

Figure 5. Confirmation of the gene array data in PC3 cells by semiquantitative RT-PCR. Total RNA was extracted from solely cultured cells (A), cells co-cultured in the insert system (I) and cells co-cultured in the contact system (C). Different genes were amplified by RT-PCR using specific primers. Human GAPDH (226 bp, showed by arrow head) was used as internal loading control.

increase the invasiveness of cancer cells. Cathepsin $\mathrm{K}$ is involved in osteoclast-mediated bone destruction (25), and is highly expressed in bone metastatic cancer cells $(26,27)$. In the present study, cathepsin K expression was increased in PC3 as well as in BMSC. However, the relative importance for events mediated by cathepsin $\mathrm{K}$ needs to be further clarified. Corey et al (28) showed that zoledronic acid inhibited PC3-induced osteolytic metastasis by repressing expression of MMP-2, MMP-9 and cathepsin K in PC3 simultaneously. It suggested that protease from prostate cancer cells played critical roles in osteolytic outcome of bone metastasis.

\begin{tabular}{|c|c|c|c|c|c|}
\hline & & \multirow{2}{*}{\multicolumn{2}{|c|}{$\begin{array}{ll}I & C\end{array}$}} & \\
\hline & & & & $\begin{array}{l}\text { Ratio } \\
\text { (I/A) }\end{array}$ & $\begin{array}{l}\text { Ratio } \\
\text { (C/A) }\end{array}$ \\
\hline $\begin{array}{l}\text { BMP6 } \\
\text { (171bp) }\end{array}$ & $\Leftrightarrow$ & $\Leftrightarrow$ & $=4$ & 1.0 & 0.4 \\
\hline $\begin{array}{l}\text { Collagen VIII } \alpha 1 \\
\text { (507bp) }\end{array}$ & $\rightarrow$ & - & -4 & 0.8 & 0.5 \\
\hline $\begin{array}{l}\text { Collagen IX } \alpha 1 \\
\quad(177 \mathrm{bp})\end{array}$ & $\Rightarrow$ & $=$ & $=4$ & 0.9 & 0.5 \\
\hline $\begin{array}{l}\text { SMAD6 } \\
\text { (533bp) }\end{array}$ & $\rightarrow=$ & & & 0.03 & 0.01 \\
\hline $\begin{array}{l}\text { TGF } \beta 1 \\
\text { (165bp) }\end{array}$ & $=$ & $\equiv$ & $=4$ & 1.2 & 1.9 \\
\hline $\begin{array}{l}\text { TWIST } \\
\text { (527bp) }\end{array}$ & - & - & 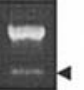 & 1.0 & 2.7 \\
\hline $\begin{array}{c}\text { Cathepsin K } \\
\text { (508bp) }\end{array}$ & E & & E. & 1.8 & 2.0 \\
\hline $\begin{array}{l}\text { Decorin } \\
(512 b p)\end{array}$ & - & 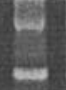 & 4 & 2.0 & 4.3 \\
\hline $\begin{array}{l}\text { TGF } \beta R 1 \\
\text { (463bp) }\end{array}$ & $=$ & - & -4 & 0.1 & 0.2 \\
\hline $\begin{array}{l}\text { TGF } \beta R 3 \\
\text { (536bp) }\end{array}$ & $\Rightarrow \equiv$ & 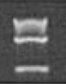 & $=$ & 2.5 & 0.3 \\
\hline
\end{tabular}

Figure 6. Confirmation of the gene array data in BMSC by semi-quantitative RT-PCR. Total RNA was extracted from solely cultured cells (A), cells cocultured in the insert system (I) and cells co-cultured in the contact system (C). Different genes were amplified by RT-PCR using specific primers. Rat GAPDH (217 bp, showed by arrow head) was used as internal loading control.

Two abundant bone-derived factors cited in the "vicious cycle' (3) of metastasis formation are TGFß and IGF. Osteoblast-derived TGFß1 enhances the invasiveness of prostate cancer cells and participates in new bone formation $(29,30)$. The expression of TGFß receptors and Smad molecules were increased in co-cultured PC3 cells, but decreased in BMSC. This suggests a dual role for TGFß in the progression of tumor metastasis and metastasis-associated bone lesions. No changes in the expression of IGF-I, IGF-II and their receptors were detected. However, IGF-BP expression was affected. IGF-BP3 is a major inhibitory-binding protein of IGF-I. The expression levels of IGF-BP3 inversely correlate with the risk of prostate cancer (31). The expression of IGF-BP3 was down-regulated by contact in the present study, consistent with a pro-metastasis effect.

As components of the MAPK pathway, mta-1, raf- 1 and MKK4 was regulated in co-cultured PC3. The metastasisassociated protein Mta-1 is highly expressed in metastatic cells. It may enhance invasion and anchorage-independent survival of metastatic cells through stimulating MAPK pathway (32). Oncogenic raf-1 is also a regulator of MAPK and extracellular-signal-regulated kinase $1 / 2$ signal transduction pathway. It may induce the production of parathyroid hormonerelated protein, which has been implicated in bone metastasis (33). As a metastasis suppressor in prostate cancer, MKK4 is a critical signal transduction molecule involved in multiple signal pathways. It links upstream MEKK1 to downstream stress-activated protein kinase and p38 MAPK (34). In the 
present study, oncogenes mta-1 and raf-1 were up-regulated, while MKK4 was down-regulated in PC3 during the co-culture with BMSC, suggesting that modification of MAPK signal transduction pathway facilitates metastatic prostate cancer cell survival in the bone environment.

The results from this study will serve as a basis for further investigation of the molecular pathways underlying bone metastasis formation. Contact mediated events between cancer cells and bone occur via separate and unique mechanisms that have not previously been targeted for therapeutic intervention. Identifying these mechanisms is a strategy that may improve the ability to selectively prevent and treat bone metastasis.

\section{Acknowledgements}

We are grateful to Kenneth Thurn, Laura Simons and Jennifer Jarrett for technical assistance; Mary Paniagua and Jeffery Nelson at the Flow Cytometry Core Facility, and Robert H. Lurie at the Comprehensive Cancer Center for expert technical support on flow cytometric analysis and cell sorting. This study was supported by the Robert Wood Johnson Foundation, Orthopaedic Research and Education Foundation (R.L.S.), and pilot grant (SPORE CA89018-01) (A.S.L.).

\section{References}

1. Jemal A, Tiwari RC, Murray T, et al: Cancer statistics, 2004. CA: Cancer J Clin 54: 8-29, 2004.

2. Koutsilieris M, Laroche B, Thabet M, et al: The assessment of disease aggressivity in stage D2 prostate cancer patients. Anticancer Res 10: 333-336, 2001.

3. Mundy GR: Metastasis to bone: causes, consequences and therapeutic opportunities. Nat Rev Cancer 2: 584-593, 2002.

4. Logothetis CJ and Lin S-H: Osteoblasts in prostate cancer metastasis to bone. Nat Rev Cancer 5: 21-28, 2005.

5. Martinez J, Silva S and Santibanez JF: Prostate-derived soluble factors block osteoblast differentiation in culture. J Cell Biochem 61: 18-25, 1996.

6. Kido J, Yamauchi N, Ohishi K, et al: Inhibition of osteoblastic cell differentiation by conditioned medium derived from the human prostate cancer cell line PC-3 in vitro. J Cell Biochem 67: 248-256, 1997.

7. Festuccia C, Bologna M, Gravina GL, et al: Osteoblast conditioned media contain TGF-betal and modulate the migration of prostate tumor cells and their interactions with extracellular matrix components. Int J Cancer 81: 395-403, 1999.

8. Hullinger TG, Taichman RS, Linseman DA, et al: Secretary products from PC-3 and MCF-7 tumor cell lines up-regulate osteopontin in MC3T3-E1 cells. J Cell Biochem 78: 607-616, 2000.

9. Andersen H, Jensen ON and Eriksen EF: A proteome study of secreted prostatic factors affecting osteoblastic activity: identification and characterization of cyclophilin A. Eur J Cancer 39: 989-995, 2003.

10. Bhattacharyya RS and Stern PH: IGF-I and MAP kinase involvement in the stimulatory effects of $\mathrm{LNCaP}$ prostate cancer cell conditioned media on cell proliferation and protein synthesis in MC3T3-E1 osteoblastic cells. J Cell Biochem 90: 925-937, 2003.

11. Yang J, Fizazi K, Peleg S, et al: Prostate cancer cells induce osteoblast differentiation through a Cbfa1-dependent pathway. Cancer Res 61: 5652-5659, 2001.

12. Pinski J, Parikh A, Bova GS, et al: Therapeutic implications of enhanced $\mathrm{G}(0) / \mathrm{G}(1)$ checkpoint control induced by coculture of prostate cancer cells with osteoblasts. Cancer Res 61: 6372-6376, 2001.

13. Fizazi K, Yang J, Peleg S, et al: Prostate cancer cells-osteoblast interaction shifts expression of growth/survival-related genes in prostate cancer and reduces expression of osteoprotegerin in osteoblasts. Clin Cancer Res 9: 2587-2597, 2003.
14. Bhattacharyya RS and Stern PH: MAP kinase involvement in responses of osteoblasts and bone to $\mathrm{LNCaP}$ prostate cancer cells. Oncology 17 (Suppl 3): 22, 2003.

15. Barille S, Collette M, Bataille R, et al: Myeloma cells upregulate interleukin-6 secretion in osteoblastic cells through cell-to-cell contact but down-regulate osteocalcin. Blood 86: 3151-3159, 1995.

16. Suzuki S, Sato M, Senoo H, et al: Direct cell-cell interaction enhances pro-MMP-2 production and activation in co-culture of laryngeal cancer cells and fibroblasts: involvement of EMMPRIN and MT1-MMP. Exp Cell Res 293: 259-266, 2004.

17. Satcher RL, Dvorkin K, Levenson AS, et al: Gene expression in cancer cells is influenced by contact with bone cells in a novel coculture system that models bone metastasis. Clin Orthopaedic Related Res 426: 54-63, 2004.

18. Levenson AS, Tonetti DA and Jordan VC: The oestrogen-like effect of 4-hydroxytamoxifen on induction of transforming growth factor alpha mRNA in MDA-MB-231 breast cancer cells stably expressing the oestrogen receptor. Br J Cancer 77: $1812-1819,1998$

19. Achbarou A, Kaiser S, Tremblay G, et al: Urokinase overproduction results in increased skeletal metastasis by prostate cancer cells in vivo. Cancer Res 54: 2372-2377, 1994.

20. Cher ML, Biliran HR Jr, Bhagat S, et al: Maspin expression inhibits osteolysis, tumor growth, and angiogenesis in a model of prostate cancer bone metastasis. Proc Natl Acad Sci USA 100: 7847-7852, 2003.

21. Stewart DA, Cooper CR and Sikes RA: Changes in extracellular matrix (ECM) and ECM-associated proteins in the metastatic progression of prostate cancer. Reprod Biol Endocrinol 2: 2-14, 2004.

22. Nemeth JA, Yousif R, Herzog M, et al: Matrix metalloproteinase activity, bone matrix turnover, and tumor cell proliferation in prostate cancer bone metastasis. J Natl Cancer Inst 94: 17-25, 2002.

23. Gohji K, Fujimoto N, Hara I, et al: Serum matrix metalloproteinase- 2 and its density in men with prostate cancer as a new predictor of disease extension. Int J Cancer 79: 96-101, 1998.

24. Moses MA, Wiederschain D, Loughlin KR, et al: Increased incidence of matrix metalloproteinases in urine of cancer patients. Cancer Res 58: 1395-1399, 1998.

25. Saftig P, Hunziker E, Wehmeyer O, et al: Impaired osteoclastic bone resorption leads to osteopetrosis in cathepsin-K-deficient mice. Proc Natl Acad Sci USA 95: 13453-13458, 1998.

26. Brubaker KD, Vessella RL, True LD, et al: Cathepsin K mRNA and protein expression in prostate cancer progression. J Bone Mine Res 18: 222-230, 2003.

27. Littlewood-Evans AJ, Bilbe G, Bowler WB, et al: The osteoclastassociate protease cathepsin $\mathrm{K}$ is expressed in human breast carcinoma. Cancer Res 57: 5386-5390, 1997.

28. Corey E, Brown LG, Quinn JE, et al: Zoledronic acid exhibits inhibitory effects on osteoblastic and osteolytic metastases of prostate cancer. Clin Cancer Res 9: 295-306, 2003.

29. Festuccia C, Angelucci A, Gravina GL, et al: Osteoblastderived TGF-beta 1 modulates matrix degrading protease expression and activity in prostate cancer cells. Int J Cancer 85: 407-415, 2000.

30. Harris SE, Bonewald LF, Harris MA, et al: Effects of transforming growth factor beta on bone nodule formation and expression of bone morphogenetic protein 2, osteocalcin, osteopontin, alkaline phosphatase, and type I collagen mRNA in long-term cultures of fetal rat calvarial osteoblasts. J Bone Mine Res 9: 855-863, 1994.

31. Li L, Yu H, Schumacher F, et al: Relation of serum insulin-like growth factor-I (IGF-I) and IGF-binding protein-3 to risk of prostate cancer. Cancer Causes Control 14: 721-726, 2003.

32. Mahoney MG, Simpson A, Jost M, et al: Metastasis-associated protein (MTA)-1 enhances migration, invasion, and anchorageindependent survival of immortalized human keratinocytes. Oncogene 21: 2161-2170, 2002.

33. Grill C, Gheyas F, Dayananth P, et al: Analysis of the ERK1,2 transcriptome in mammary epithelial cells. Biochem J 381: 635-644, 2004.

34. Yoshida BA, Dubauskas Z, Chekmareva MA, et al: Mitogenactivated protein kinase kinase 4/stress-activated protein/Erk kinase 1 (MKK4/SEK1), a prostate cancer metastasis suppressor gene encoded by human chromosome 17. Cancer Res 59: 5483-5487, 1999 . 